\title{
GREAT EXPECTATIONS, UNCERTAIN FUTURES. URbAN AND ONLINE ENCOUNTERS WITH YOUTH, LOVE AND MARRIAGE IN EGYPT
}

\author{
Senni JYRKIÄINEN, Victoria BISSET ${ }^{*}$
}

\begin{abstract}
For young Egyptians, the economic and social instability of recent years has led to a prolonged period of youth with marriage, a key life event, now occurring later in life. Although social media and greater access to higher education have created more opportunities for unmarried men and women to meet, and have at least in principle paved the way for young people to marry for love, in practice, issues such as a lack of financial means and the pressure for women to marry soon after graduation mean that such marriages remain the exception rather than the norm.
\end{abstract}

Keywords - Youth; relationships; marriage; love; social media; future; uncertainty; Egypt; Middle East

Résumé - Pour les jeunes égyptiens, l'instabilité économique et sociale des dernières années a contribué à une prolongation de la jeunesse et à un recul de l'âge au mariage, un évènement clé dans la vie en Egypte. Bien que les médias sociaux, et un accès plus large à l'enseignement supérieur, offrent davantage d'opportunités de rencontres aux jeunes hommes et femmes célibataires et aient, en théorie, rendu possible les mariages d'amour, ces derniers restent, en pratique, plutôt exceptionnels en raison du manque de moyens financiers et de la pression exercée sur les femmes afin qu'elles se marient rapidement après la remise du diplôme.

Mots-clés - Jeunesse ; relation ; mariage ; amour ; médias sociaux; avenir ; incertitude ; Egypte ; Proche-Orient

Resumen - Para los jóvenes egipcios, la inestabilidad económica y social de los últimos años, contribuyó a una prolongación de la juventud y a un retroceso de la edad del matrimonio, evento clave en la vida en Egipto. Aun cuando los medias sociales, y un acceso más amplio a la enseñanza superior, ofrecen más oportunidades de encuentros con muchachas y muchachos solteros y, en teoría, hayan hecho posible los matrimonios de amor, estos últimos son, en la práctica, más bien excepcionales, debido a la falta de medios financieros y a la presión ejercida sobre las mujeres, con el fin de que se casen pronto, después de la obtención del título.

Palabras claves - Juventud; relación; matrimonio; amor; medias sociales; porvenir; incertidumbre; Egipto, Oriente Medio

\footnotetext{
* Senni Jyrkiäinen, Doctoral Candidate, Social and Cultural Anthropology, University of Helsinki, Finland, senni.jyrkiainen@helsinki.fi; Victoria Bisset, B.A., King's College, University of Cambridge, U.K., victoria.bisset@cantab.net
} 


\section{INTRODUCTION}

MARRIAGE HAS TRADITIONALLY HELD a central position in Egyptian youths' plans for their futures. It is a project that involves not only the young couple, but also both of their families. The relationship between marriage and love is a complex one, not least because of the economic issues which affect the young most acutely. In recent years, political turbulence has further complicated young people's future aspirations, a matter which we will examine in this article.

As the editors of Love in Africa (Cole \& Thomas 2009) have noted, there is little scholarship on the sentiments of attachment in Africa, even though Africanist scholars have widely addressed other emotions, such as anger and jealousy. Recognising the epistemological and methodological questions that touch upon the study of love and intimacy, the writers suggest that love be approached "as an analytic problem rather than a universal category" (Cole \& Thomas 2009: 3), since contemporary practices and ideologies of love in Africa, as anywhere else, are products of longer historical processes.

Within anthropological studies of Africa, several books have been written relatively recently about representations of youth (see for example Christiansen et al. 2006; Cole \& Thomas 2009). An important shift in the anthropological literature on Muslim-majority North Africa has occurred as researchers have come to recognise the value of youth-centred research. Ted Swedenburg (2007), for example, argues that the notion of "youth" has to be understood as a social and cultural product of modernity, while Linda Herrera and Asef Bayat (2010) have highlighted the importance of looking at the strategies used by Muslim youth to realise their aspirations. It may be argued that, given the large proportion of young people in Egypt's population, their viewpoint merits the increased attention it has gained in recent years.

Our article aims to contribute to this discussion by focusing on the impact of social pressures and future uncertainty on the lives and relationships of young Egyptians. More precisely, it seeks to understand how youths discuss their expectations and experiences of love and marriage, both on social media and in their everyday lives, amid the political, social and economic instability that has followed the 2011 Egyptian Revolution. We study two questions: What are the aims and expectations of young women and men in the context of romantic relationships and future marriage? And what possibilities and obstacles do they foresee in their quest to find love?

We approach these questions by analysing narratives of a specific group of women and men with regards to issues such as romance, marriage, gender and new technologies in post-revolutionary Egypt. Since the process of getting married, which focuses on the formation of new kin relations, is a highly gendered process, we consider that a gender-sensitive approach is very much needed, and therefore seek to address the particular challenges faced by young men and women respectively. By including social media in our study, we aim to go beyond the political lens that has 
characterised discussions of modern youth culture since the 2011 uprisings in the Middle East and North Africa, and instead focus on the use of social media as a tool for debating social issues such as love and marriage.

The empirical evidence of this study is derived from fieldwork conducted by the authors in Egypt's second city of Alexandria between 2012 and 2014. For a researcher studying youths, this coastal city of almost 5 million inhabitants is an interesting research site, owing to the presence of a vibrant youth culture scene which has only expanded since the 2011 revolution, with the emergence of new cultural spaces and the creation of online groups to bring together people with similar interests.

We use ethnographic methods and social media sources to argue that urban life has to be studied through an intersectional lens that provides perspectives on gender and the period of youth. Alexandria's "youthscapes" are "not just geographic or temporal, but social and political" sites too (Maira \& Soep 2013: 15). We try to look at how the very presence of the youth in the city's "youthscapes" and their practices are perceived by the surrounding community, families and young people themselves. However, before discussing life on campus, which is one of the central "youthscapes" in Alexandria, we look at the literature on youth and love in Egypt.

\section{“WE WERE MARGINALISED FOR SO LONG"}

The history of youth-centred research that seeks to incorporate the voices of young people is not very long (Herrera 2010). Despite this, youths and children, once considered to be anthropology's silent "others" (Caputo 1995), are increasingly viewed as active subjects and their opinions are given greater consideration than was previously the case.

In the Egyptian context, there has been a growing concern with young people since the 1980s, either because of demographic issues or expectations related to the modernisation process (Herrera 2010; Swedenburg 2007). According to Linda Herrera (2010), Middle Eastern youths have been treated in the literature either as proponents of neoliberal development or as being religious with radical tendencies, but have rarely been consulted about their struggles. Nowadays, however, the region's youths are not merely perceived as troublemakers, but rather as consumers taking part in a global capitalist youth culture (Swedenburg 2007). In Egypt, the Arab Spring has arguably given greater prominence to the voice of the youth than any other event in the country's recent history. To quote a young Alexandrian man: "We were marginalised for so long." 1

Youths, defined as 18 to 29-year-olds by CAPMAS (2012), represent a quarter of Egypt's population. However, economic problems such as unemployment and

\footnotetext{
${ }^{1}$ Research for this paper was conducted in both Arabic and English, and unless otherwise stated, translations are the authors' own. Transliteration in this article follows the system of The International Journal of Middle Eastern Studies, with slight modifications for words in Egyptian Colloquial Arabic, with $g$ replacing $j$ and 'replacing $q$.
} 
underemployment disproportionately affect young people. According to official measures, as many as 25 percent of this age group are currently without formal employment (Amin 2012; CAPMAS 2012). These issues are linked to the ongoing socio-political crisis, and though the revolution gave the youth a chance to speak out, it did not offer an escape from economic misery or social inequality.

The current situation, in which even highly educated young people have few immediate prospects of finding steady or well-paid employment, has led to an extended period of youth, and many young people remain financially dependent on their parents for longer than they would like. Married life, which for men is generally dependent on fulfilling certain financial obligations such as owning an apartment and paying a dowry, must therefore wait. Simultaneously, products of modernity such as an extensive higher education system and an emerging youth culture in urban areas have contributed to this protracted period of youth (Swedenburg 2007).

Herrera (2010: 131) appositely describes the frustration of Egyptian youths who feel that they are "embarking on a transition not to adulthood, but a transition to nowhere." Economic problems limit their ability to realise future plans or to move on in life. A period that is supposed to be temporary becomes increasingly protracted.

How do we then understand youth in this study? As Ted Swedenburg (2007) writes, it is "a socially and culturally determined category, a transitional phase between childhood and adulthood that, in its contemporary form, is a product of modernity." Nowadays this period may last many years, and in this article, we understand youth as a flexible category; instead of focusing on a strictly-defined age group, we have chosen to look at young people who have not yet married. When using youth as an analytical category, it is important to be aware of the inner divisions created by class, culture, gender, and other factors (Bayat \& Herrera 2010). In urban areas of Egypt, the issue of gender is particularly pertinent to any discussion of youth, as it has been noted that young men may belong to this social category well into their thirties because they lack the economic resources to get married or fulfil other social markers of adulthood (Swedenburg 2007). We will discuss this problem in this article.

The young generation that grew up under Mubarak and formed the forefront of the 2011 revolution are using new technologies for political, social and cultural rebellion. Egypt's "wired youth" (Herrera 2014) are blogging and chatting and sharing their views about subjects that touch their lives. We will look at online discussions about love and marriage, and the ways in which changes in ideas about relationships have been reflected on social media. While the impact of social media on youth culture in the revolutionary context has been widely studied, few studies have focused on romantic relationships between youth in the Middle East in the social media age (Kaya 2009; Schielke 2011). 


\section{MARRIAGE IN EGYPT}

“Getting married here [in Egypt] is like getting a driving license. It's just a matter of procedures and getting permissions. It has nothing to do with emotions, has nothing to [do] with love, has nothing to [do] with anything, has nothing to do with the boy and girl. [It's] just like if you're applying for a job and there are criteria you have to meet. That's it." (Sharif, 23, engineering student) ${ }^{2}$

The anthropological literature has looked at the various aspects and forms of the Egyptian marriage institution, including match-making and marriage negotiations, the popularity of arranged and love marriages, unregistered 'urfi and ambulant misyār marriages, consanguineous marriages et cetera, as well as its religious, social and financial aspects (Abaza 2001; Hasso 2011; Hoodfar 1997; Singerman 1995; Sonneveld 2012). Focusing on the lives of popular classes in Cairo, Homa Hoodfar (1997) and Diane Singerman (1995) describe how families choose suitable partners and negotiate marriages for their children. More recent research on the Middle East highlights the active role of the youth themselves in dating and match-making (Kaya 2009; Schielke 2015).

The involvement of the family in marriage arrangements was also highlighted by our informants. Karim, an unmarried 25-year-old engineering student, explains that even though he has no personal experience of marriage, his observations of his own circle of friends and relatives have informed his view that marriage is a family matter. Karim himself has no intention of marrying in the near future and instead hopes to move abroad to study or work. In his own words, "marriage in Egypt is not necessarily only motivated by individual's need to satisfy (...) emotional, mental, and sexual needs, but [is] also motivated by complicated social traditions, it is considered as a 'two-families-project' rather than a 'two-persons-project' that [requires] a lot of decision-making, directions, and even funds from people other than the two main actors." (Karim, 25)

As Karim makes clear, marriage is not solely a union based on emotional attachment. Thus while romantic love emerges as a significant element of young people's narratives of marriage during the course of our research, we should not assume that romantic love is sought by all brides and grooms. Marriage, as Karim states, is a complex project.

This complexity of marriage has been studied in recent anthropological literature on Egypt. In his book Egypt in the Future Tense, Samuli Schielke describes love as a promise and an experience as follows:

“Love (...) is powerful partly as an experience and partly as a promise, and although as a promise it can take the form of a supreme power that overwhelms everything else, as an experience it usually exists in a complex and often tense coexistence along with everything else. (...) And nowhere else are the conflicts and contradictions of romantic

\footnotetext{
${ }^{2}$ All names in this article have been changed and informants have been assigned a pseudonym.
} 
love, sexual mores, respect, and family connectivity as strong and as urgent as they are in the struggles to bring love and marriage together." (Schielke 2015: 93)

Engineering student Sharif (23), who is quoted in the beginning of this chapter, strongly believes that decisions pertaining to marriage are out of young people's control. He is in a romantic relationship but feels that he has little hope of marrying his girlfriend because of her family's material expectations of any potential suitors.

Indeed, marriage in Egypt is not understood "as a partnership between individuals but rather as an alliance between two families" (Hoodfar 1997: 55), and is guided by various legal, religious and cultural norms, which define the rights and duties of both husband and wife. In a Muslim marriage, for example, the groom has to pay the mahr (dowry) to the bride and is responsible for providing for his family. He has the right to marry as many as four wives and to restrict the physical mobility of his spouse(s). The wife, in turn, is entitled to maintenance. In the marriage contract, the couple can further define their rights by offering women an equal right to divorce or preventing men from taking additional wives, for instance (Hoodfar 1997; Sonneveld 2012). The unequal status of the husband and wife in the case of divorce and the natal family's responsibility to support a divorced woman can explain the eagerness of the bride's family to arrange a secure marriage for her (Hoodfar 1997).

Importantly, marriage has traditionally offered "the primary framework for the expression of masculinity and femininity and the fulfilment of gender roles" (Hoodfar 1997: 52). However, our informants felt that nowadays, young husbands are not always able to fulfil their roles as independent breadwinners of their families. Young couples are sometimes forced to rely on parental support if their income is insufficient to cover the costs of the family.

Suad Joseph (2005) has argued that Arab states base their state-citizenry relations on "the kin contract" which is an idealized model of social relations. The kin contract presumes that all subjects are both gendered and aged. Gender here is understood as "a cultural set of rules that are defined as appropriate to the sexes in a given society at a given time" (Singerman \& Hoodfar 1996: 33). Additionally, subjects are familial and thus committed to complementary rights and responsibilities within the kin unit. So it is also in marriage.

In the following chapters, we shall examine how young women and men discuss expectations of marriage and hopes for love against the backdrop of uncertain economic conditions, social pressures and gender relations. We look at how youths actively negotiate, preserve and challenge norms that shape romantic gender relations and the marriage institution in Egypt.

\section{Methodology}

In this article, we combine ethnographic data with social media sources. In social media, we have followed blogs, chats and user profiles, and analysed them against 
the observations extracted from the field. Subjects that we discuss here are raised by bloggers as well as by our informants. The bloggers we have followed deal with issues that touch Egyptian youth and young people's everyday lives.

All of the ethnographic data used in this article was collected in Alexandria between 2012 and 2014 and, with the exception of the work of one blogger whose work is introduced below, all online and social media accounts referred to also belong to young people living in the city. Participant observation and interviews with young, unmarried men and women have been essential to this research in providing us with an insight into youth perspectives. Focus group discussions were also organised at the city's library, Bibliotheca Alexandrina ${ }^{3}$. After each group session, participants wrote essays about the subject under discussion. Additionally, some specialists were interviewed for the study, such as an Alexandrian psychiatrist working with young people ${ }^{4}$.

We aim to analyse "the whole social arrangement through a sexual lens" (Hatem 1986: 249) in order to understand the ways in which gendered mechanisms shape relationships between young men and women. We discuss how youths (re)negotiate their hopes and expectations in light of a turbulent present and an uncertain future, and compare the narratives of young men and women to identify different ways of speaking about love and marriage.

In addition, we have selected two Arabic-language blogs written by young Egyptian women, which deal with issues and concerns that affect youths. I Want to Get Married is a blog created by Ghada Abdel Aal in 2006, which has since been turned into a best-selling book and popular TV series. Although Abdel Aal does not live in Alexandria and most of her writing predates the 2011 revolution, her work reflects the issues facing modern, educated, urban women and echoes the views and concerns of many of our informants. Nahla Elnemr is an Alexandrian blogger and author of Something on my Mind. By choosing two female bloggers, we were able to analyse women's voices and analyse issues that concern young educated women specifically, such as the pressure to marry soon after graduation.

The youth interviewed for this study are students or graduates of different public and private universities in Alexandria. Hence, gaining a university-level education represents an essential part of the period of youth of our informants. In spite of the

\footnotetext{
${ }^{3}$ Jyrkiäinen organised the focus group sessions in cooperation with the Unit of Futuristic Studies at the Bibliotheca Alexandrina. Although the library is a state institution, the Alexandrian students and graduates who participated in the sessions spoke frankly and raised a variety of social and political views on the subjects under discussion. In this article, we utilise data from the session that dealt with marriage in Egypt.

${ }^{4}$ During the years 2013 and 2014, Jyrkiäinen conducted fieldwork for her PhD in Alexandria. Besides participant observation, interviews and focus group sessions, she collected data from social media sites. Bisset spent 2012-2013 as a listening student at Alexandria University, during which time she also conducted interviews and analysed social media for her undergraduate dissertation. The two authors also conducted a number of interviews together specifically for the purposes of this article.
} 
fact that all of our interviewees come from Muslim families, the worldviews of the youths involved vary from secular to religious. The focus group sessions included both Muslim and Christian participants.

Alexandrian "youthscapes" form a central part of our focus. In addition to attending university lectures and private courses, students spend their time in Alexandria's many cafés, malls, social clubs, cinemas and parks. Leisure time spent in public and commercial spaces is part of the middle-class culture. Most youths participating in our study are active in virtual spaces as well, and are engaged in online activities. Even though both female and male students go out and spend time in the city, mobility in the city is clearly gendered. Female students and mixedgender groups are a common sight in Alexandria's upmarket cafés, whereas groups consisting only of men prefer to sit in 'ahāwi (local coffee houses that are traditionally male-only spaces, although this is changing in some areas). Young women are expected to come home around the time that young men are often just beginning their night. The university campus, however, is one place where the two sexes regularly come into contact.

\section{LOVE ON CAMPUS}

Owing to the gender segregation in place in most secondary schools in Egypt, young people entering university for the first time often have little experience of interacting with unrelated individuals of the opposite sex. At the same time, as Schielke (2011) has shown, love has long held an important place in Arabic literature and poetry, and contemporary Egyptian society and popular culture continues to place a high value on the idea of romantic attachment. Even otherwise conservative young people who believe in the strict separation of the sexes may still have strong views on the merits of love. Universities are therefore well-known sites of romance but, as we shall see, young people's idealistic conceptions of romance and their dreams of marrying for love often come into direct conflict with both social norms governing male-female relationships and the reality of economic hardships.

Love on campus is a subject that was discussed both on social media and by our informants. Blogger Ghada Abdel Aal writes about the romantic relationships between students, which she jokingly refers to as "the 'Sweethearts System'", and the "exactly six Sweetheart couples" that she recalls from her student years (2010: 31). As the blog demonstrates, attitudes towards gender mixing on university campuses may vary considerably from one student to another and between families. In general, upper class and upper-middle class youth are associated with mixed-gender spaces and networks (Armbrust 1999; De Koning 2009), whereas among the middle-income circles to which Ghada belongs, contact between unmarried men and women often appears as a morally problematic practice. For Ghada, "Male-Free was the only way to go" (2010: 31), and she would talk to boys only when it was necessary for her studies. "There's no messing around with the morals!" she would tell herself when 
she watched films where male students would trick girls who had less strict interpretations of religion and morality (Ghada: 34).

Some female students we spoke to were open to dating or at least having friends of the opposite sex, while others wholly disapproved of such relationships and refrained from any unnecessary contact with male classmates. In Cairo and Alexandria, attitudes towards dating are more permissive than in other Egyptian towns or cities, but even so, romantic relations between unmarried youths are monitored everywhere and scrutinised by the moralising gaze of the community, as was pointed out by our informants. However, as Frances Hasso (2011) has shown, mobile phones and other new technologies have eased private communication and expanded access both to friends and partners in the Middle East. Some female students who reported not spending time in mixed-gender groups on campus spoke of private communication with the opposite sex in virtual spaces.

Among those informants who were open to dating is Dina (21), a final-year student at Alexandria University. Her family is Muslim but she, like many of her friends, describes herself as an atheist. Dina would like to have a boyfriend but feels that fulfilling emotional and physical needs is made difficult for young people by "social shaming". She adds that the societal pressures that limit sexual relations make liberal youth like her feel threatened. Another student, Shaima' (19), is in her first year of university and shares Dina's frustrations. She is also from a Muslim family, but personally rejects the influence of culture and religion on young people's lives and relationships. Shaima' explains that although sexual relations outside of marriage do sometimes occur, in reality it is very difficult for young couples to spend time alone together, as the majority either live with their families or in single-sex university dormitories. Hotels, according to her, would not accept unmarried couples.

As Kaya (2009) has shown in the context of Jordan, the religious and cultural importance given to personal and family honour and the potential damage that spending time alone with an unrelated male could cause to an individual or family's reputation means that such a decision is not undertaken lightly by young women.

Because of this, romantic relationships often flourish only inside the walls of the university campus, and even there, physical intimacy is not tolerated. While gender segregation is not enforced in universities, in the first- and second-year classrooms and lecture halls regularly visited by one of the authors in Alexandria University's Faculty of Arts, male students would automatically drift towards the back of the

\footnotetext{
${ }^{5}$ The words "boyfriend" and "girlfriend" have been used throughout this article in reference to romantic attachments between young people prior to engagement or marriage, although it should be noted that the nature of such relationships differs greatly from the connotations of the words in English, as will be shown. These words, and their abbreviations, "BF" and "GF" respectively, were used by a number of informants in both English and Arabic; other young people used generic Arabic terms for a male or female friend (șāhib/șāhibah).
} 
room, while their female classmates would sit in the front rows. Outside of the classroom, however, in the department corridors and around the many stalls selling stationery and snacks, the mixing of the sexes as part of larger friendship groups occurred more frequently, though single-sex groupings remained the norm.

In this sense, the university campus served as a microcosm of Alexandrian life, in which the presence of older adults (in this instance professors) led to a more formal separation of the sexes, just as on public transport, where unacquainted men and women would avoid sitting together where possible. In areas with less direct supervision from older adults and the greater anonymity this offered, however, groups of friends could come together and socialise more freely, and members of the opposite sex could interact as part of these friendship groups. Among the young people we spoke to who had experience of dating, it was very rare for couples to spend time alone even off-campus, preferring instead to go to cafés or to the city's public gardens as part of a larger group and limiting private contact to the virtual sphere, as we will see below.

Our male informants offered their own perspectives on dating on campus. Wa'il (23) originally comes from a small town outside of Alexandria. He completed his undergraduate studies at Alexandria University and is now a Master's student, and lives alone in the city. Wa'il recalls that he once had a crush on a girl in his class and explains that they were "talking for three months", but that going on a date was impossible because her family found the whole idea of dating shameful. Thus Wa'il and the girl were only able to spend time together on campus. Wa'il's friends were in the same situation with their girlfriends.

While student couples can often only meet on campus, they can communicate through social media all night long without their parents' knowledge. Wa'il and his friends have met many girls through Facebook and say that having online relationships is easy nowadays. However, in Wa'il's experience, the chances of entering into an intimate relationship or even kissing a girl are rare in their social circles. 'Abdallah (25), a friend of Wa'il, is a recent graduate who now works in the army. 'Abdallah explains that young women usually avoid intimacy because of the censure they will face if their relationship becomes known within the community.

The restrictions placed on young women by their families mean that going on a date can be tricky even for those prepared to accept the risk of being discovered in the company of unrelated men. Women's mobility is generally guarded by their parents and brothers, and whereas young men socialise quite freely, unmarried women often have a curfew and their families expect to know where and with whom they are going out. Although this aspect of life has been often been explained as a tool of patriarchal control over women in Egypt and elsewhere in the Middle East and North Africa (Ghannam 2002), both female students and their mothers cited security concerns and social instability following the 2011 revolution as major obstacles to young women seeking to go out with friends. Thus while Wa'il and 
'Abdallah, like most men of their age, were able to sit with their friends in 'ahāwi (local cafés) until the early hours of the morning, Dina was expected to return home by a certain time each evening and was not allowed to go out at all on Fridays because of her parents' fears for her safety during the protests that often followed Friday prayers. Other young women also mentioned that their families would not allow them to meet with their friends on weekends or public holidays as, in addition to the increased instances of sexual harassment on city streets on these days, during the period of research (and particular during and immediately following the year of Muslim Brotherhood rule in Egypt), these days were popular times for demonstrations.

As a result of these restrictions, young couples seeking to spend time together may skip lectures or take advantage of free periods in their timetables to visit nearby cafés or the city's public gardens as part of a group. As Shaima' explains, such outings are particularly advantageous for young women, as they already have their family's permission to be outside of the home and, so long as they return home by the usual time, their parents never suspect they have been anywhere other than their regular lectures.

Ideologically, the control imposed on young females fits into the model of the patriarchal Arab family. Mervat Hatem defines patriarchy as "historical systems of institutionalized male control of female sexuality" (1986: 249). Even though fathers and brothers do have the power to control young females in the family, our female informants reported that it is often mothers who make the phone calls to check where their daughters are and decide when and how often they can go out.

A young couple may try to keep their relationship secret, but if they want to take the next step and get engaged they must first inform their families. Marriage negotiations start when the groom's family approaches the bride's family. If the response is negative, campus love is doomed to end in a tragic way.

\section{LOVE MARRIAGE VERSUS THE “LIVING ROOM" MARRIAGE}

In Arab countries, family is at the heart of society in every sense (Joseph 2003). Marriage creates a new family unit and getting married is therefore arguably the most important life event for young Egyptians. Love marriages and arranged marriages are both common among the younger generation. In the case of the socalled living room marriage (gawwāz al-șāluñat), the couple is introduced to each other for the first time in the presence of the family, whereas in love marriages, the families become involved only when marriage negotiations start.

Thus, regardless of the way the couple meets, the presence of both families is essential to the negotiations and preparations for marriage. As such, entering into marriage is not a private affair between the young couple, even if their relationship is based on love. Prevailing patriarchal social structures and ideologies affect marital selection, though not all young people agree with these principles. Negotiations 
include such components as the material contribution of the bride and groom, the new household, the mahr (dowry), and arrangements of daily life (Hoodfar 1997).

Men are supposed to provide for the family after getting married and this pressure to be financially independent can be seen in the narratives of our male informants, Wa'il tells the stories of two of his friends. 'Ali was in a relationship with a classmate for two years at university. One day his girlfriend came and told him that she had got engaged the day before. "That was like a shock for all of us", Wa'il recalls. Whereas 'Ali's girlfriend had opted for an arranged marriage, another friend, Muhammad, chose to marry his girlfriend of five years for love.

While he understands that Muhammad got married because he did not want to lose the woman he loves, Wa'il does not think that entering the marriage was the right decision for Muhammad, who now struggles to make ends meet:

"[Getting married] wasn't the right choice to do because when [Muhammad] graduated he was still unemployed and he got married because he was under pressure: she wanted to get married and he couldn't leave her. At the same time he was supposed to find a job, so he was ready to accept any job. So that's the point. He didn't give himself time to discover what he wants. What does he want to do [in] his future! He put himself under this pressure, like he had to get a job [so] that he can pay the rent or like everything that his family needs." (Wa'il, 23)

In Egypt, "the Sweethearts System" rarely results in a marriage because campus couples lack the means to get married. A bride's family is highly unlikely to approve a suitor whose financial status is unstable. Wa'il explains the situation: "The girls and the boys in the college think differently. (...) The girl wants someone to marry her. Maybe a few of them are looking for a serious relationship or like a serious love. But most of them are looking for someone to marry them. (...) That's the point, that's the thing that makes it very, very difficult. Because the guys are not ready yet to get married after they graduate." (Wa'il, 23)

After graduation men are supposed to look for a job and to work hard for several years to earn all the money needed for marriage and an apartment. Some parents are able to help their sons financially but many middle-class families struggle just to make a living. Because of the shortage of jobs or the social connections often required to gain well-paid jobs, many young men either fail to find employment or are forced to undertake menial or low-paid jobs that effectively prevent them from gaining the material wealth or social status necessary to marry quickly. Consequently, a large age gap is a typical feature of married couples in Egypt, with at least a quarter of recently-married women aged at least ten years younger than their husbands (Rashad et al. 2005).

Ayman (23) graduated as an engineer but now works as a waiter in a café. He earns less than 1000 Egyptian Pounds ${ }^{6}$ per month and thinks that he will have to

\footnotetext{
${ }^{6}$ Approximately 110 Euros.
} 
work for at least 15 years before he can afford to get married. Like many young Egyptians, Ayman sees working abroad as the only solution to his financial difficulties, and hopes that a relative will be able to help him find a job in the Emirates.

Whereas university-educated men are expected to find a job after graduation, women are generally expected to get married soon after leaving university. Many women report that the pressure to get engaged and married increases in their final year of studies or immediately after graduation; otherwise, a woman risks being labelled a spinster.

Partly because of the different expectations and pressures faced by female and male graduates, 'Sweetheart couples' often break up. As Wa'il states, while men would like to continue dating, a female graduate has to start looking for a husband. According to Wa'il, men usually start to think about marriage later than women: "If the girl is like 22 or 23 , she is in trouble because she shall get married soon. Not like the boys. They are getting married around 27 or 28. (...) [Consequently, a] 27-yearold guy is marrying a 21-year-old girl and that's the problem here." (Wa'il, 23)

We spoke to several young men who were bitter about the fact that women often prefer wealth to love. However, from a female perspective, the decision often comes down to a choice between unstable and secure future prospects. Unmarried Nuha (27) graduated some years ago and now works in a state institution. She has had some frustrating experiences of meeting suitors and is aware of the difficulties involved in finding a suitable husband. She explains the logic that prevents women from marrying the one they love:

"I'll marry him maybe because his financial situation is better than [that of] the one I love and I want to marry someone in a good position. He will afford me a good standard of living. And the one I love, maybe he doesn't have much money to put me in the life I want to be in. (...) Maybe because we don't have the chance to develop ourselves (...), because I know that everything is closed in our faces [here in Egypt] so I don't have this chance. So I prefer to marry the one who will [at least] (...) afford my living". (Nuha, 27)

Nuha's comments reflect the insecurities of the post-revolutionary period in which this research was carried out. Although the economic difficulties faced by young individuals and couples are by no means new and predate the 2011 uprising, the effect of the political and social turmoil of recent years on the morale of young people has been significant. Many people we spoke to lamented the failure of the revolutionary slogans of 'Bread, freedom and social justice' to address their needs or improve their lives in any tangible sense, and shared Nuha's feeling of having no opportunities to proceed in life. This general sense of despondency among Egyptian youths may in part explain why, despite the idealised image of love prevalent among the urban population, so many young women remain willing to trade romantic 
attachment for financial security in their future marriages. In the next chapter, we shall look at the pressures unmarried women face in Egyptian society.

\section{A SPINSTER AT THE AGE OF 22}

According to the report 'Marriage in the Arab World' (Rashad et al. 2005), marriage is almost universal in Egypt, with less than 5 percent of women aged 35 to 39 having never married. The report clearly shows that the timing of marriage varies across the Arab region. Among Egyptian females, more than 50 percent of 20-to-24year-olds are married; however, highly-educated women generally marry later than less-educated women. In Egypt, the average age at marriage for women who are at least high school graduates is 24 , which is three years higher than for women with no education. The statistical data helps us understand the pressure that unmarried women face in Egyptian society.

Expectations to marry after graduation are actively discussed by female bloggers and female university graduates alike. Blogger Nahla writes: "When girls reach a certain age and haven't got married, they get called 'spinsters'. It's annoying, right?" Both men and women face pressure to get married, but the issue arises earlier for women.

We observed that marriage was a common subject of discussion between unmarried daughters and their mothers. Some mothers were active in looking for spousal candidates while some young women expressed their wish to deal with the matter themselves. Rahma (22) is a recent graduate and comes from a very religious family. She describes herself as secular and feels restrained by her parents' strict rules. She has a secret boyfriend and dreams of travelling and living abroad, but for the moment she is stuck in Alexandria. Rahma has been to more than 20 job interviews but has been unable to find a job. Her mother talks about marriage all the time, and Rahma is forced to meet suitors even though she is not interested in marriage at the moment. She sighs when she recounts that although she is only 22, her mother already calls her 'ānis (spinster).

Shirin (27) is a graduate who works in a state institution and who rejects the idea of dating. She currently works two jobs and is very focused on her career. For Shirin's family, it has been difficult to accept her willingness to stay single:

"My parents keep pushing me to marry with the tradition of gawwāz al-șālūnāt (the living room marriage) (...) Of course, as a 27-year-old single lady, I am stressed by the judgments of my friends and relatives that I experience in my everyday life because single women have to fight; to find a husband, or to avoid comments of other people! However, after a long fight with my family, I persuaded them to stop forcing me to meet strange grooms." (Shirin, 27)

Just as young people mentioned high expectations when discussing potential marriage partners, so there was a sense that those who had not yet married must therefore be flawed or deficient in some way. For men, such deficiencies may be material in nature (e.g. not being able to afford the religiously-mandated dowry, or 
meet social expectations such as having a "good" job or owning an apartment), or moral, as blogger Nahla explains: "When guys reach a certain age and haven't got married, they say worse things, like that he must not want to get married because he's engaged in immoral activity, or that he's not married because he can't get married!" (Elnemr 2015).

However, most of our informants agreed that "immorality", such as premarital sexual relations, was much less of a concern for men than for women; indeed, some young people, such as Nuha, seemed to expect that men would have had previous relationships before getting married.

Nuha, who we introduced earlier, recounts a conversation she once had with her mother, in which she asked what her mother would say if one of her children were to marry someone who had previously been in an intimate relationship. Her mother replied that she would understand if Nuha's future husband had had sexual relations before marriage, but that she would never allow her son to marry a girl who was not a virgin.

An Alexandrian psychiatrist argues that this attitude is not limited to mothers. While sexually-experienced young men do not see their own premarital relations as morally problematic, most of them still want to marry a woman who has not been in any type of relationship before. Thus, from a female perspective, dating can be a risky business, and women may therefore refrain from mentioning any previous relationships or emotional attachments to their fiancés or husbands, even if there was no physical element to the relationship.

Despite the possible issues faced by those who do choose to date, women who remain single past a certain age are also viewed negatively, and being a "spinster" is perceived by many in society to be a personal failing. In a 2014 speech about her experiences of being unmarried in her thirties, blogger Ghada Abdel Aal mentions that of all the reactions to her work, she has been most surprised by those of women who, like herself, are over 30, single, and very successful in their respective professions (Abdel Aal 2014). When, for example, she mentioned that her blog was being turned into a TV series, the reactions of those she was with changed from initial admiration to shock at the choice of a beautiful lead actress: "They said: 'Hind Sabri, how can that be? The girl who wants to get married has to be ugly!"

More often than not, however, a woman's physical appearance is regarded as less of an impediment to finding a suitable marriage partner than her career success. In the same speech, Ghada recounts the story of a highly-educated and financially independent young Egyptian woman who reached a high position in a multinational company. "And then she found herself at the age of 28, and felt like something was missing [...] She resigned from the company, sold her car and threw away her jewellery and went to work in a governmental company, got married and now has three children." (Abdel Aal 2014) 
Ghada expresses bewilderment at the expectation that professional women must compromise their professional or educational goals if they ever hope to get married: "Society is always telling you to give up on your ambitions because the higher up you go, the more difficult it is for you to find someone to be with. I mean, he should have to come up to my level, why should I have to be the one to lower myself?" (Abdel Aal 2014)

The difficulties of finding a well-educated husband who is not afraid of marrying a knowledgeable and successful woman with an equal or higher level of education was discussed by both female bloggers and our informants. Many young women felt that in order to find a spouse they would have to downplay or hide their intellectual abilities and career ambitions. This point is related to the expected gender roles which we will discuss next.

\section{THE WOMAN HE LOVES HE WILL NOT MARRY}

Expectations surrounding gender roles in marriage are related to the ideals of a patriarchal family. In Egyptian society, men have traditionally been viewed as the breadwinners of the family, whereas women have had the main responsibility for child rearing and the household. However, structural changes in society such as industrialisation and changing state ideologies and labour market conditions have clearly influenced the Egyptian household and its gender roles (Ghannam 2002; Hoodfar 1997; Singerman \& Hoodfar 1996). The spread of secondary and tertiary education and women's increased participation in the labour force have blurred the distinction between provider and homemaker. Deniz Kandiyoti correctly argues that women's rights have become "part of an ideological terrain where broader notions of cultural authenticity and integrity are debated and where women's appropriate place and conduct may be made to serve as boundary markers" (1992: 246). As Farha Ghannam (2002) has noted, women are sometimes seen as negatively influenced by the effects of globalisation and their new identities as travellers and consumers of goods and global images, for instance, are under criticism.

Nuha and Shirin's cases exemplify the contradictory positions of working, careeroriented women. Both are unmarried and in their late twenties. They live with their parents but have formal employment and are financially quite independent. These ambitious women agree with blogger Nahla who argues that all the struggles men have to go through to get married makes them very demanding in terms of spousal criteria. At the same time, these women feel that most men have little else to offer but economic security.

Nuha does not believe that "Sweetheart couples" break up solely because of financial problems. She confirms that men look for different types of women when choosing to date or get married:

"I think men here like obedient women. They like a woman [whose mind] they can control. Here (...) men always keep telling that the woman they love, they will not marry her. And the woman we will marry, we will not love her. They will [marry a] 
woman they will feel comfortable with. The girl they love will be maybe bothering them all the time with her questions, with her opinions. So they don't have to marry her. So they always think that they want to marry someone like their mum." (Nuha, 27)

As mentioned above, blogger Nahla believes that because men have to work so hard to be able to get married, they are only interested in finding a "perfect" bride:

"Every young man has to struggle a lot until he can afford to get married, and this may delay marriage for a while. And just as he has had to struggle and be patient, so he wants the perfect bride; the bride that will dazzle everyone when they see her, so that they will say to him, 'You're so lucky, man!' The bride that all the young guys will envy him for (...) And of course this bride is exactly what he wanted - she's the most beautiful girl there is! And the prettier she is, the more she becomes the perfect bride." (Elnemr 2015)

Shirin thinks that men have become very demanding but have little to offer themselves:

"Due to the increase in prices and the difficulty of living, most of Egyptian men do not marry until they reach their 30s or 40s. At this point, a man starts searching for an imaginary woman that is only real in his mind. In fact, I am not against marriage, but I totally hate this image of immature (...) men who are too selfish and needy before and after marriage. Even they are not at the same level of maturity of women nowadays, a nightmare that keeps trapping us girls after marriage in Egypt. (...) My biggest dream is 'not to find a husband'; I do not want to be finally destroyed by a man who is too selfish to notice my problems." (Shirin, 27)

These educated, financially independent women are looking for companionship but soon discover it is difficult to find. Women like Nuha have noticed that while a man might enjoy the company of a quick-witted girlfriend, he may be reluctant to have a wife with such a strong personality. Nuha believes that in the end, men prefer to marry someone who will not challenge them intellectually. A woman with wit, life experience and a higher education can be considered too knowledgeable and capable in the eyes of many men.

Nuha's comments reflect the fears of many young women who are open to the idea of dating, that their more outspoken and liberal attitudes may come in the way of marriage. Other young women felt that men's differing preferences when it came to selecting a bride were closely linked to the central role of the family in the marriage process. While many young men and women would like to marry for love and may regard romantic relationships as the way to achieve this, in reality most young people are unwilling to go against their parents' wishes. Both men and women may therefore accept spousal candidates based on their parents' preferences, including, as we have seen, a mother's insistence that her son marry a virgin bride, or fears that a woman interested in pursuing a career may neglect her domestic duties.

Whatever the reason, many young women are acutely aware of this discrepancy between the type of woman that men claim to find attractive and those they 
ultimately marry, and may consequently alter their use of social media when they begin meeting suitors or want to attract marriage partners in order to present a more favourable image. Both men and women mentioned this phenomenon, with young men ruefully recounting the many female friends from university who, shortly before getting engaged or married, had deleted their former male classmates from social media accounts so as to assert themselves as "respectable" women who did not socialise with members of the opposite sex. Young women were equally dismissive of such practices, and cited examples of female friends and acquaintances who would remove photos of themselves from their Facebook profiles and instead shared religious verses and imagery, in order to demonstrate their modesty and religiosity.

Ghannam (2002: 90) argues that the attempts to control women's participation in work life are a way to control not only "the female body and female sexuality" but that "[t]here is also a strong desire to control women's minds, the knowledge they have access to, and the kind of solidarities they may form." This argument about women's access to the workplace can be applied more widely to gain a better understanding of expected gender roles and power inequalities in marriage. Homa Hoodfar (1997) has shown how men often see a direct link between their role as the principal breadwinner and their masculinity. Our data, again, shows that work is an essential part of the identity of many educated, career-oriented women. While some women are ready to compromise between their career and marriage, as discussed in the previous chapter, other women decide to resist the pressures to get married just because they are expected to, in order to pursue other goals.

The disappointment and frustration of educated young women shows how delicate an issue the criteria of marital selection is and how changing social roles and responsibilities may lead the youth to reconsider the ideal models of a wife and a husband. The male point of view on this aspect remains a subject for further study.

\section{CONCLUSION}

Love and marriage are subjects actively discussed by Egyptian youths. In the beginning of this article we asked what the aims and expectations of the young people are in the context of romantic relationships and future marriage, and what possibilities they have to realise their hopes. We introduced two female bloggers who use the virtual sphere to comment on the problems related to their search for a loving partner and husband. We also presented a group of young, unmarried Alexandrian students and graduates whose voices represent a variety of different views on the subjects of campus love, arranged versus love marriage, spinsterhood and criteria of marital selection. We analysed narratives of men and women and identified some differences between them.

While many unmarried youths place great importance on the idea of love and use social media to share quotes about romance and companionship, in practice, finding a balance between love and social expectations and obligations can prove to be a gruelling, if not impossible, task. Neither campus nor online romances lead 
automatically or easily to marriage. Even though opportunities to meet the opposite sex online and offline and to experience love before marriage have increased, the new ways of gender-mixing have not necessarily eased the requirements of marriage or lessened the practical or emotional involvement of families in spouse selection. While dating and romantic relationships can potentially strengthen the image of a popular, masculine man, dating can put young women's reputations at risk, at least if it happens off-campus. However, the spread of new technologies and the widespread use of social media among educated, urban youths has opened up opportunities for online love and secret dating.

Although matrimony forms a central life event in Egyptian society, increasing numbers of educated men and women do not agree with the idea of getting married simply to gain the social status that comes with marriage. For women, the pressure to get married often becomes greater soon after graduation and some females are constantly told "to try harder" to find a spouse and to avoid the looming fate of becoming a spinster. Men have to bear a great part of the financial burden of marriage in a country where youth unemployment is among the highest levels in the world. Thus while female students are encouraged to marry soon after completing their higher education, male graduates are expected to find a job and marry later. Consequently, a campus couple may find it difficult to proceed in marriage if they are not lucky enough to have families who are able to help them financially.

A quick look at Egyptian Facebook walls may give the false impression that love and marriage always go hand in hand. Despite the flourishing online culture of romance and idealised love, many middle-class Egyptians opt for an arranged marriage as a financially reasonable and morally accredited alternative. Those in favour of the 'living room marriage' rely on the idea that "love comes after marriage". When a marriage is negotiated, be it a love or an arranged marriage, the family of the bride wants to ensure that the groom is able to provide for the family. These high material requirements have led some young men to accuse women of preferring wealth and status to love. Women, on the other hand, often complain that men tend to look for a meek yet beautiful bride while having little else to offer save material wealth. Furthermore, some women feel obliged to downplay their own success in the fields of education and work in order to avoid fuelling the insecurities of potential suitors.

The 2011 uprisings across the Middle East and North Africa offered hope to a new generation that an end was finally in sight to years of economic stagnation and social and political marginalisation. However, in the five years that have passed since the first demonstrations in Cairo's Tahrir Square, these heady expectations have given way to a realisation that change is often slow to appear, and that social and cultural norms may be particularly resistant to adaptation. Yet while ideals surrounding courtship and marriage do not change overnight, neither do they stay the same forever. As we have seen, the impact of the post-revolutionary period on the 
personal relationships of young Egyptians has been varied, with some young people seeking stability in traditional forms of marriage in the face of an uncertain future, while elsewhere the spread of new technologies has offered youths the opportunity to challenge cultural and social norms. In the virtual sphere in particular, the critical voices of young educated Egyptians suggest a wider reconsideration of attitudes towards dating, social shaming related to sexual intimacy before marriage, financially burdening marriage customs and criteria of spouse selection. They challenge some commonly-held beliefs according to which a successful adult has to be married and have children.

Questions related to love and marriage are sensitive because they touch on issues that are very much related to the formation of the central unit of Egyptian society, the family. Discussions on online platforms about expectations of love and marriage have led youth debates on marital roles, gender issues and some taboo subjects as well. In the end, however, social, political and economic instability may force young people to compromise between love and economic stability.

\section{BIBLIOGRAPHY}

AbAZA M. 2001 «Shopping Malls, Consumer Culture and the Reshaping of Public Space in Egypt », Theory, Culture \& Society $18:$ 97-122.

AbDel AAL G. 2010 I Want to Get Married! One Wannabe Bride's Misadventures with Handsome Houdinis, Technicolor Grooms, Morality Police, and Other Mr. Not Quite Rights. Austin, Texas: University of Texas Press.

AbDel AAL G. 2014 "Thirty-Something: Ghada Abd El Aal at TEDx Cairo Women », YouTube, retrieved 23 September 2016 : [https://www.youtube.com/watch?v=AyhfiL4s5e0]

AMIN J. 2012 Madha hadatha li-l-thawra al-misriyya? Cairo : Dar al-Shuruq.

ARMBRUST W. 1999 «Bourgeois Leisure and Egyptian Media Fantasies », in D.F. Eickelman \& J.W. Anderson (eds.) New Media in the Muslim World: The Emerging Public Sphere (102-128). Bloomington : Indiana University Press.

BAyAt A. \& Herrera L. 2010 Being Young and Muslim. New Cultural Politics in the Global South and North. Oxford-New York : Oxford University Press.

CAPMAS (Central Agency for Public Mobilization and Statistics) 2012 Statistics: Population. State Information Service.

CAPUTO V. 1995 «Anthropology's Silent 'Others' : A Consideration of Some Conceptual and Methodological Issues for the Study of Youth and Children's Cultures », in V. Amit-Talai \& H. Wulff (eds.) Youth Cultures: A Cross-Cultural Perspective (19-42). London-New York: Routledge.

Christiansen C., UtAS M. \& VigH H. 2006 Navigating Youth, Generating Adulthood. Social Becoming in an African Context. Uppsala : The Nordic Africa Institute.

Cole J. \& ThOmas L. 2009 Love in Africa. Chicago: University of Chicago Press.

ELNEMR N. 2015 «Shay'un fi dhihni », retrieved 23 September 2016 : [http://zehny.blogspot.co.uk] GHannam F. 2002 Remaking the Modern: Space, Relocation, and the Politics of Identity in a Global Cairo. Berkeley-Los Angeles : University of California Press.

HASSO F.S. 2011 Consuming Desires: Family Crisis and the State in the Middle East. Stanford: Stanford University Press. 
Hatem M. 1986 « The Politics of Sexuality and Gender in Segregated Patriarchal Systems: The Case of Eighteenth- and Nineteenth-Century Egypt », Feminist Studies 12(2) : 251-274.

HerRerA L. 2010 "Young Egyptians' Quest for Jobs and Justice», in A. Bayat \& L. Herrera (eds.) Being Young and Muslim: New Cultural Politics in the Global South and North (127-144). Oxford: Oxford University Press.

HERRERA L. 2014 Revolution in the Age of Social Media: The Egyptian Popular Insurrection and the Internet. London-New York : Verso.

Hoodfar H. 1997 Between Marriage and the Market: Intimate Politics and Survival in Cairo. Berkeley-Los Angeles : University of California Press.

JOSEPH S. 2003 "Gender and Family in the Arab World», in S. Sabbagh (ed.) Arab Women: Between Defiance and Restraint (194-202). New York: Olive Branch Press.

Joseph S. 2005 "The Kin Contract and Citizenship in the Middle East», in M. Friedman (ed.) Women and Citizenship (146-169). Oxford : Oxford University Press.

KANDIYOTI D. 1992 "Women, Islam, and the State : A Comparative Approach », in J.R.I. Cole (ed.) Comparing Muslim Societies: Knowledge and the State in a World Civilization (237-260). Ann Arbor : University of Michigan Press.

KAYA L.P. 2009 "Dating in a Sexually Segregated Society: Embodied Practices of Online Romance in Irbid, Jordan », Anthropological Quarterly 82(1) : 251-278.

De Koning A. 2009 Global Dreams : Class, Gender, and Public Space in Cosmopolitan Cairo. Cairo : American University in Cairo Press.

MAIRA S. \& SOEP E. 2013 Youthscapes: The Popular, the National, the Global. Philadelphia: University of Pennsylvania Press.

RASHAD H., OSMAN M. \& Roudi-FAHIMI F. 2005 « Marriage in the Arab World », Population

Reference Bureau, retrieved 23 September 2016 :

[http://www.prb.org/pdf05/marriageinarabworld_eng.pdf]

SCHIELKE S. 2011 « 'Aid al-hubb fi misr : Qira'atun fi al-jadal al-dini wa-l-thiqafi », Marāșid $7: 5$ 36.

SCHIELKE S. 2015 Egypt in the Future Tense: Hope, Frustration, and Ambivalence before and after 2011. Bloomington : Indiana University Press.

Singerman D. 1995 Avenues of Participation: Family, Politics, and Networks in Urban Quarters of Cairo. Princeton-New Jersey : Princeton University Press.

Singerman D. \& HoOdfar H. 1996 Development, Change, and Gender in Cairo: A View from the Household. Bloomington : Indiana University Press.

SONNEVELD N. 2012 «Rethinking the Difference between Formal and Informal Marriages in Egypt », in M. Voorhoeve (ed.) Family Law in Islam: Divorce, Marriage and Women in the Muslim World. London-IB Tauris : 77-107.

Swedenburg T. 2007 «Imagined Youths », The Politics of Youth, Middle East Report 245 : 4-11. 